\title{
Population and Diversity of Birds in the Kodanadu Area of Nilgiris, Western Ghats of Tamilnadu, South India
}

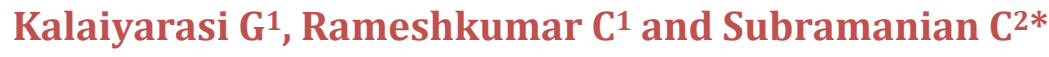 \\ ${ }^{1}$ Department of Zoology and Wildlife Biology, India \\ ${ }^{2}$ Department of Zoology, India
}

*Corresponding author: Subramanian Chinnathambi, Department of Zoology, Government Arts College (Autonomous), Kumbakonam-2, Tamil Nadu, India, Tel:

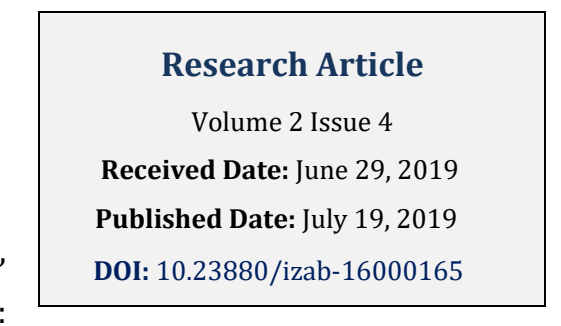
09943515085; Email: csubramanian24@yahoo.co.in

\begin{abstract}
The abundance of birds consisting of 46 species, 8 orders and 25 families were recorded. The maximum number of sightings was obtained in the house sparrow (Passer domestics). The lowest number of sightings ( $\mathrm{n}=4 ; \mathrm{ER}=0.06 / \mathrm{km}$ walked) were had in the Great Hornbill (Buceros bicornis) from overall observations. The Encounter Rate was high for house sparrow Passer domesticus (25.9/km) in the rainy season and low for Greater Coucal Centropus sinensis $(\mathbf{0 . 0 7} / \mathrm{km})$ when compared to other species. The Encounter Rate of birds in the study area in different seasons (Rainy and Summer) were observed with the variations. In summer season, the Encounter Rate was high for house sparrow Passer domesticus $(27.25 / \mathrm{km})$ and in the rainy season low for Great Hornbill Buceros bicornis $(0.05 / \mathrm{km})$ when compared to other species. The other bird species were moderately found in the ER. In the study area, the diversity index was estimated using the alpha diversity. The overall diversity index (alpha diversity) of birds in the study area was observed low (-1232). The seasonal wise, the index were showed -1372 in summer and-1152 in rainy seasons.
\end{abstract}

Keywords: Biodiversity; Birds; Kodanadu; Nilgiris Western Ghats

\section{Introduction}

Birds are widely recognized as good bio indicators of the quality of the ecosystems and the health of environment [1,2]. The Birds are an important component of the forest ecosystem play a major role as consumer and disperser of plants, seeds and controllers of inset population. The scavenging bird species assist in cleaning environment, while others control crop and animal pests, and some serve as indicators, of changes in environmental quality. The changes in the status of birds may warn of habitat loss and modifications and can indicate the likely impact of these threats on other animals and plants [3].
The studies of avian community are effective tools for monitoring forest ecosystems globally. Birds are responsive to change; their diversity and abundance can reflect ecological trends in other bio diversities. Because of their highly specific habitat requirements, birds are increasingly intolerant of even slight ecosystem disturbances. The habitat structure, diversity and their relationship with the fauna provides information about the habitat utilization which ultimately leads to the management and monitoring species, habitats and the ecosystem. The information on status and distribution of species especially threatened and endemic birds, in 
prediction of distribution level and conservation efforts at all potential sites of their occurrence [4-6].

A few preliminary surveys were done by Sudha, et al. [7] in some areas in the Nilgiris. Some parts of Nilgiris were studied for baseline data on avifaunal population and its diversity [8]. Some of the baseline study on avian population and diversity were carried out by Sivakumar, et al. [9] Angel Deva Sheela, et al. [10], Mahalakshmi, et al. [11], Karthick, et al. [12], Chandrasekar, et al. [13] in the patches in the Nilgiris.

Apart from the some preliminary surveys were done by various workers in very few areas, in Nilgiris on the ages still there was a gap to fulfill and to do the documentation of avian study on population and diversity in the upper Nilgiris. Due to the lack of scientific information on the abundance, population and diversity of different species of birds in the Nilgiris, the present study was designed and carried out in the s elected areas in the upper Nilgiris.

\section{Materials and Methods}

The study for abundance and population of bird species was carried out from the selected intensive study areas. The study of abundance and population and its diversity was studied by the following methods and described.

\section{Methods for Birds Abundance and Population}

The Line transect method as described by Burnham, et al. [14] Buckland, et al. [15] and was adopted for estimating the abundance and population of avifauna in the study areas of study areas and adjoining areas. The line transects that were laid in different direction in the study areas. In which, the data on species, and individuals for avian fauna were collected while sighting on the transects. The line transects were also laid in the different altitudinal gradient and available habitats. The Nilgiris it consisting of Shola patches, deciduous, ever green and semi ever green habitats and harbours variety of faunal diversity [16].

\section{Study Area}

The study was carried out in the Kodanadu area (Kodanadu, Ealada, Nedugula, Suntatti). It is a tourist spot near Kotagiri town, in Nilgiri District of Tamil Nadu. This area is located about $18 \mathrm{~km}$ east of Kotagiri on the eastern edges of Nilgiris $\left(11^{\circ} 31^{\prime} 29^{\prime \prime} \mathrm{N} 76^{\circ} 54^{\prime} 57^{\prime \prime} \mathrm{E}\right)$. It covers an area of $10 \mathrm{sq} \mathrm{km}$. Kodanadu View Point is the one of the main view spot and it ranged up to $2734 \mathrm{msl}$ and it covers $19.20 \mathrm{Sq} \mathrm{km}$ area. And it comprises more than 16 villages. Temperature ranges from $20^{\circ} \mathrm{C}-29^{\circ} \mathrm{C}$ in summer and the annual rain fall in the Kodanadu area is $1100 \mathrm{~mm}$. The rainfall varies between $1000 \mathrm{~mm}-1500 \mathrm{~mm}$. The wild animals such Elephant (Elephus maximus), Leopard (Panthera pardus), Common Langur (Presbytis entellus), Gaur (Bos garous), Barking deer (Muntiacus muntjak), Samber Deer (Cervus unicolor), Porcupine (Hystrixindica), Himalayan Mouse Hare (Ochotona roylei), Black-naped Hare(Lepus nigricollisnigricollis), Indian Wild Boar (Sus scrofa), Squirrel (Ratufa indica) are found in the study area. This area consists of natural forest areas and Tea plantation along with vegetable cultivations Maps $1 \& 2$.

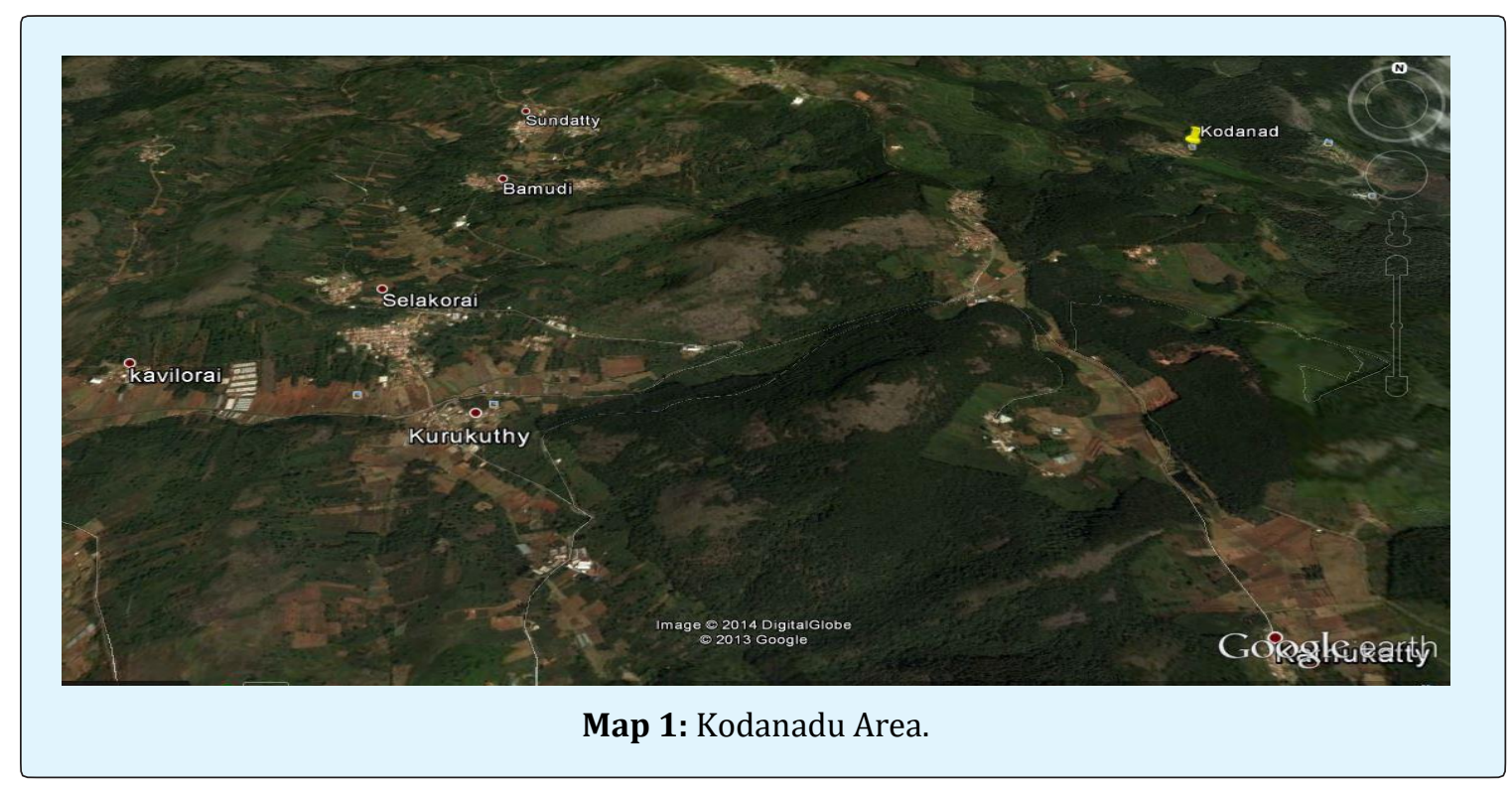

Subramanian C, et al. Population and Diversity of Birds in the Kodanadu Area of Nilgiris, Western Ghats of Tamilnadu, South India. Int J Zoo Animal Biol 2019, 2(4): 000165. 


\section{International Journal of Zoology and Animal Biology}

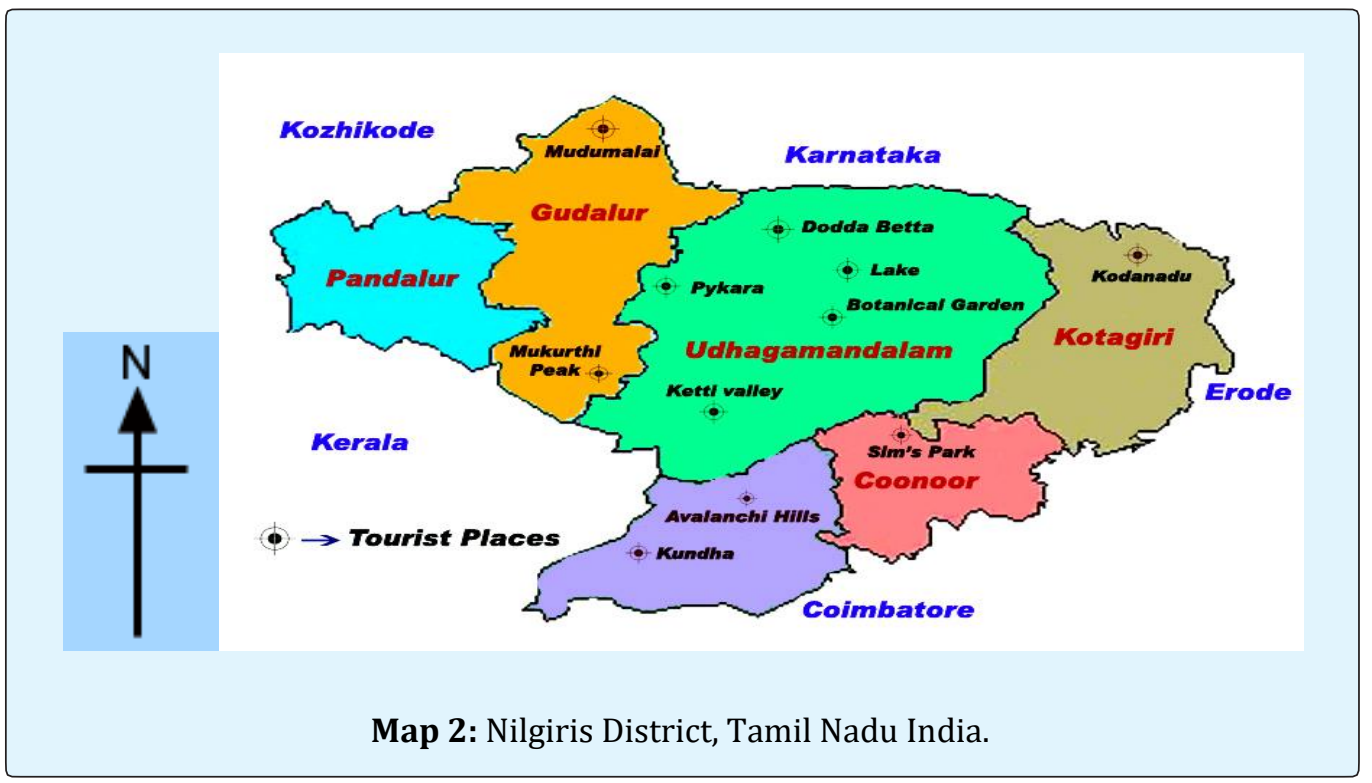

\section{Results}

\section{Population of Birds in Kodanadu Forest Area}

A total of 46 birds species were had in all the transect during the study period. The abundance of birds was estimated as Encounter Rate (ER)/ $\mathrm{km}$ walked in the field. Out of 4543 individuals, the maximum number of sightings (Encounter Rate $=28.13 / \mathrm{km}$ walked) were obtained in the house sparrow (Passer domestics). The lowest number of sightings ( $\mathrm{n}=4 ; \mathrm{ER}=0.06 / \mathrm{km}$ walked) were had in the Great Hornbill (Buceros bicornis) from overall observations. The Encounter Rate was high for house sparrow Passer domesticus $(25.9 / \mathrm{km})$ in the rainy season and low for Greater Coucal Centropus sinensis $(\mathbf{0 . 0 7} / \mathrm{km})$ when compared to other species (Table 1).

\begin{tabular}{|c|c|c|c|c|c|}
\hline S.NO & Common Name & Species Name & Rainy seasons & Summer seasons & Overall \\
\hline 1 & Indian Black Eagle & Ictinaetus malayensis & 0.68 & 0.48 & 0.52 \\
\hline 2 & Tawny Eagle & Aquila rapax & 0.39 & 0.61 & 0.46 \\
\hline 3 & Painted Bush-quail & Perdicula erythrorhyncha & 0.18 & 0.35 & 0.25 \\
\hline 4 & Grey Junglefowl & Gallus sonneratii & 1.56 & 1.72 & 1.91 \\
\hline 5 & Indian peafowl & Pavo cristatus & 0.11 & 0.22 & 0.34 \\
\hline 6 & Spotted Dove & Streptopelia chinensis & 1.84 & 1.93 & 1.31 \\
\hline 7 & Emerald Dove & Chalcophaps indica & 0.34 & 0.31 & 0.36 \\
\hline 8 & Malabar parakeet & Psittacula columboides & 0.21 & 0.26 & 0.44 \\
\hline 9 & Vernal Hanging-parrot & Loriculus vernalis & 1.23 & 1.36 & 1.57 \\
\hline 10 & Common koel & Eudynamys scolopacea & 0.09 & 0.08 & 0.08 \\
\hline 11 & Greater Coucal & Centropus sinensis & 0.07 & 0.07 & 0.09 \\
\hline 12 & Great Hornbill & Buceros bicornis & 0.09 & 0.05 & 0.06 \\
\hline 13 & Streak-throated Woodpecker & Picus xanthopygaeus & 0.71 & 0.43 & 0.42 \\
\hline 14 & Common Flameback & Dinopium javanense & 0.85 & 0.24 & 0.35 \\
\hline 15 & Nilgiri Pipit & Anthus nilgiriensis & 1.07 & 1.08 & 1.08 \\
\hline 16 & Yellow Wagtail & Motacilla flava & 0.91 & 0.47 & 0.41 \\
\hline 17 & Grey Wagtail & Motacilla cinerea & 1.87 & 1.36 & 1.35 \\
\hline 18 & Scarlet Minivet & Pericrocotus flammeus & 0.09 & 0.09 & 0.08 \\
\hline 19 & Red-Whiskered Bulbul & Pycnonotus jocosus & 4.86 & 4.26 & 4.79 \\
\hline 20 & Red-Vented Bulbul & Pycnonotus cafer & 0.55 & 0.06 & 0.58 \\
\hline 21 & Yellow browed Bulbul & Acritillas indica & 0.89 & 0.41 & 0.26 \\
\hline
\end{tabular}




\section{International Journal of Zoology and Animal Biology}

\begin{tabular}{|c|c|c|c|c|c|}
\hline 22 & Oriental Magpie-robin & Copsychus saunaris & 0.81 & 0.53 & 0.8 \\
\hline 23 & Pide bushchat & Saxicola caprata & 1.71 & 1.47 & 1.25 \\
\hline 24 & Indian Robin & Saxicoloides fulicatus & 0.49 & 0.36 & 0.31 \\
\hline 25 & Kashmir Flycatcher & Ficedula subrubra & 0.89 & 0.43 & 0.54 \\
\hline 26 & White-Bellied Blue-flycatcher & Cyornis pallipes & 0.08 & 0.09 & 0.07 \\
\hline 27 & White-browed Fantail & Rhipidura aureola & 0.65 & 0.35 & 0.33 \\
\hline 28 & White-spotted Fantail & Rhipidura albogularis & 0.43 & 0.41 & 0.27 \\
\hline 29 & Common Tailorbird & Orthotomus sutorius & 0.53 & 0.57 & 0.39 \\
\hline 30 & Grey-breasted Prinia & Prinia hodgsonii & 0.51 & 0.36 & 0.21 \\
\hline 31 & Ashy Prinia & Prinia socialis & 0.36 & 0.33 & 0.29 \\
\hline 32 & Thick-billed Babbler & Acrocephalus aedon & 0.48 & 0.25 & 0.28 \\
\hline 33 & Puff-throated Babbler & Pellorneum ruficeps & 0.69 & 0.39 & 0.22 \\
\hline 34 & Yellow-billed Babbler & Turdoides affinis & 0.36 & 0.22 & 0.23 \\
\hline 35 & Great Tit & Parus major & 0.28 & 0.09 & 0.07 \\
\hline 36 & Black-lored Tit & Parus xanthogenys & 0.82 & 0.72 & 0.54 \\
\hline 37 & Purple-rumped Sunbird & Leptocoma zeylonica & 0.36 & 0.08 & 0.09 \\
\hline 38 & Oriental Whit-eye & Zosterops palpebrosus & 0.75 & 0.43 & 0.41 \\
\hline 39 & Long-tailed Shrike & Lanius schach & 1.85 & 1.51 & 1.71 \\
\hline 40 & Brown Shrike & Lanius cristatus & 0.78 & 0.61 & 0.3 \\
\hline 41 & House Crow & Corvus splendens & 7.82 & 7.87 & 8.15 \\
\hline 42 & Large-billed Crow & Corvus macrorhynchos & 9.36 & 6.21 & 7.1 \\
\hline 43 & Common Myna & Acridotheres tristis & 7.47 & 3.8 & 3.75 \\
\hline 44 & House Sparrow & Passer domesticus & 25.9 & 27.25 & 28.13 \\
\hline 45 & White-billied Drongo & Dicrurus caerulescens & 0.36 & 0.21 & 0.25 \\
\hline 46 & Common Rosefinch & Carpodacus erythrinus & 0.28 & 0.09 & 0.07 \\
\hline
\end{tabular}

Table 1: Encounter Rate of birds in different summer seasons (ER/km walked).

The Encounter Rate of birds in the study area in different seasons (Rainy and summer) was observed with the variations. In summer season, the Encounter Rate was high for house sparrow Passer domesticus $(\mathbf{2 7 . 2 5} / \mathrm{km})$ and in the rainy season low for Great Hornbill Buceros bicornis $(\mathbf{0 . 0 5} / \mathrm{km})$ when compared to other species. The other bird species were moderately found in the ER (Table 1). A total of 4543 individuals of birds were obtained from all over observations in the study area. The abundance of birds consisting of 46 species, 8 orders and 25 families were recorded (Table 2 \& Figures 1-3).

\begin{tabular}{|c|c|c|c|c|}
\hline S.No & Order & No. of. Sp & Family & No. of. Sp \\
\hline 1 & Falconiformes & 2 & Accipitridae & 2 \\
\hline 2 & Galliformes & 3 & Phansianidae & 3 \\
\hline 3 & Columbiformes & 2 & Columbidae & 2 \\
\hline 4 & Psittaciformes & 2 & Psittacidae & 2 \\
\hline 5 & Cuculiformes & 2 & Cuculidae & 2 \\
\hline 6 & Coraciifores & 1 & Bucerotidae & 1 \\
\hline 7 & Piciformes & 2 & Picidae & 2 \\
\hline 8 & Passeriformes & 32 & Campephacillidae & 3 \\
\hline 9 & - & - & Pycnonotidae & 1 \\
\hline 10 & - & - & Turdidae & 3 \\
\hline 11 & - & - & Muscicapidae & 3 \\
\hline 12 & - & - & Rhipiduridae & 2 \\
\hline 13 & - & - & Cisticolidae & 2 \\
\hline 14 & - & - & Sylviidae & 3 \\
\hline 15 & - & & \\
\hline
\end{tabular}




\begin{tabular}{|l|l|l|l|l|}
\hline 16 & - & - & Timaliidae & 2 \\
\hline 17 & - & - & Paridae & 2 \\
\hline 18 & - & - & Nectarinidae & 1 \\
\hline 19 & - & - & Zosteropidae & 1 \\
\hline 20 & - & - & Laniidae & 2 \\
\hline 21 & - & - & Corvidae & 2 \\
\hline 22 & - & - & Sturnidae & 1 \\
\hline 23 & - & - & Passeridae & 1 \\
\hline 24 & - & - & Dicruridae & 1 \\
\hline 25 & - & - & Fringillidae & 1 \\
\hline
\end{tabular}

Table 2: Order and Family-wise abundance of birds in Kodanadu during the study period.

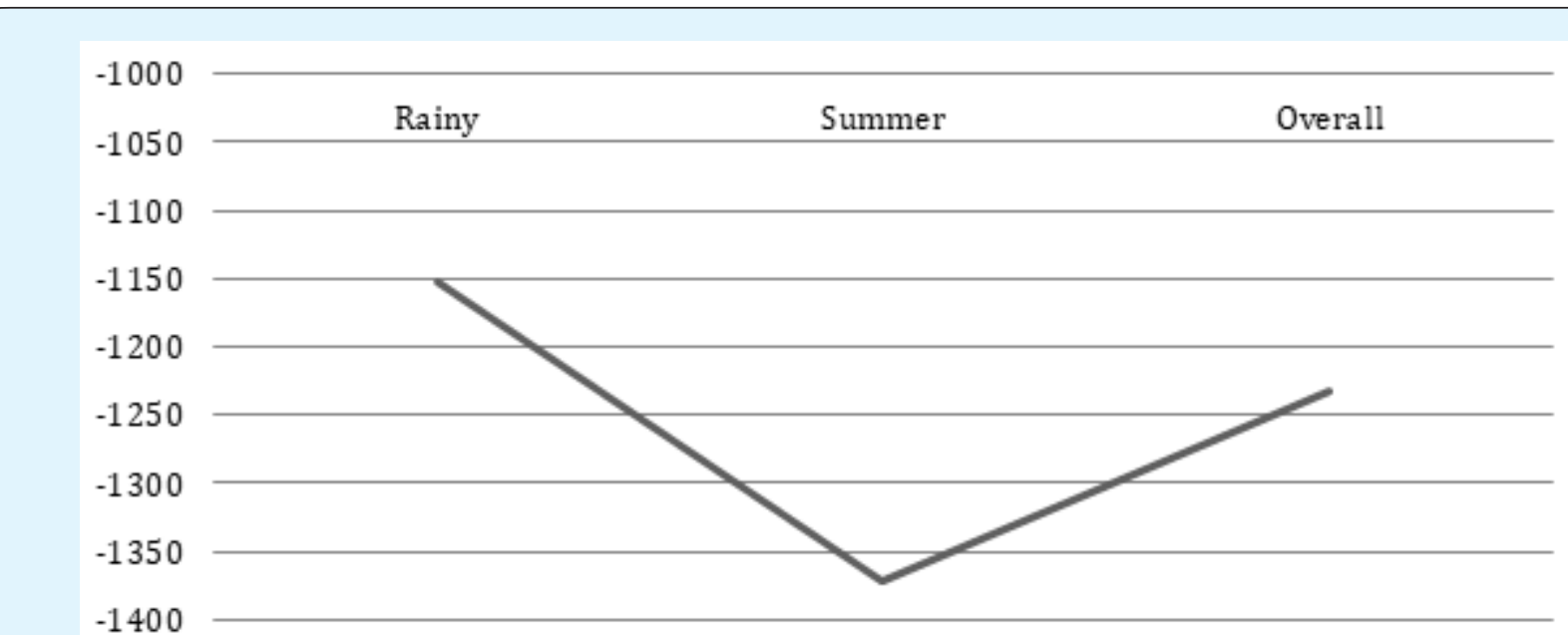

Figure 1: Shannon index of diversity ( $\alpha$ diversity) for birds abundance in different seasons ( $n=$ diversity index).

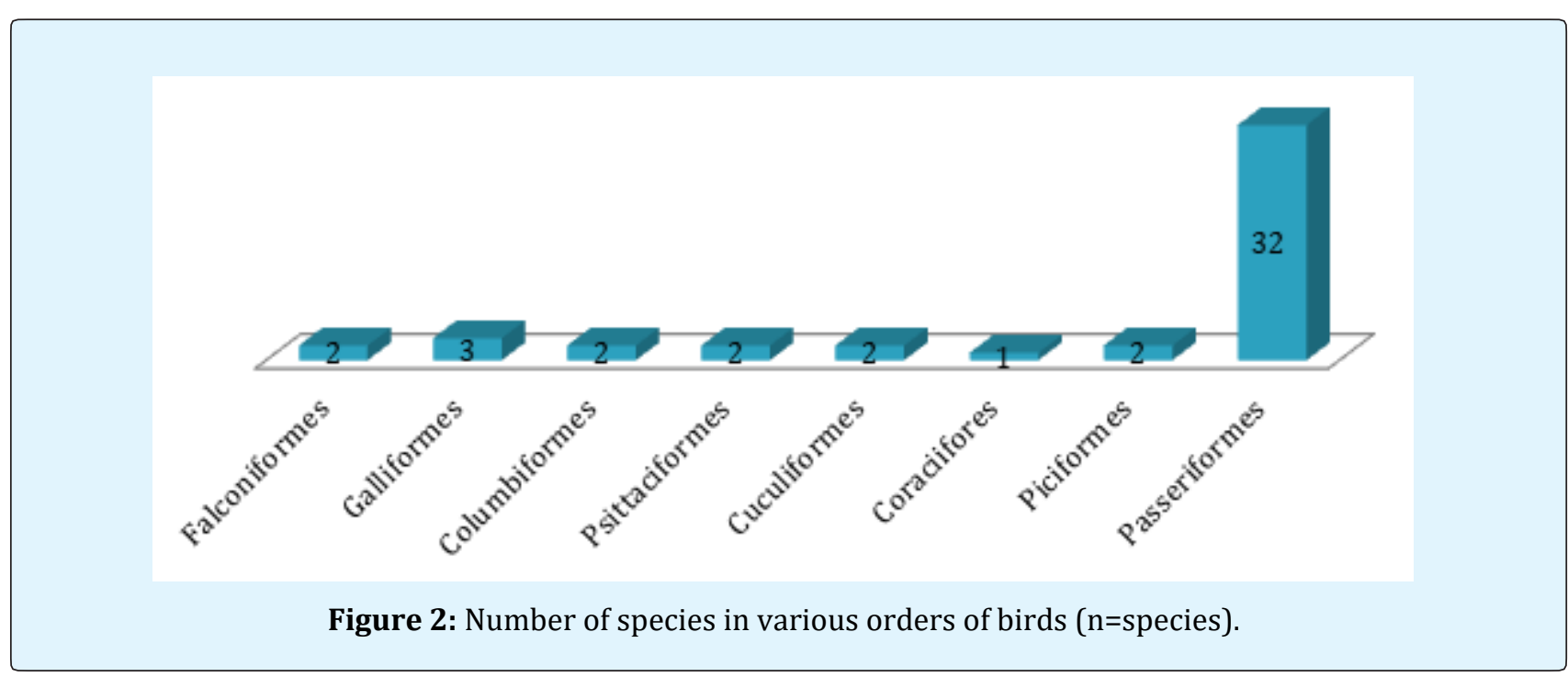




\section{International Journal of Zoology and Animal Biology}

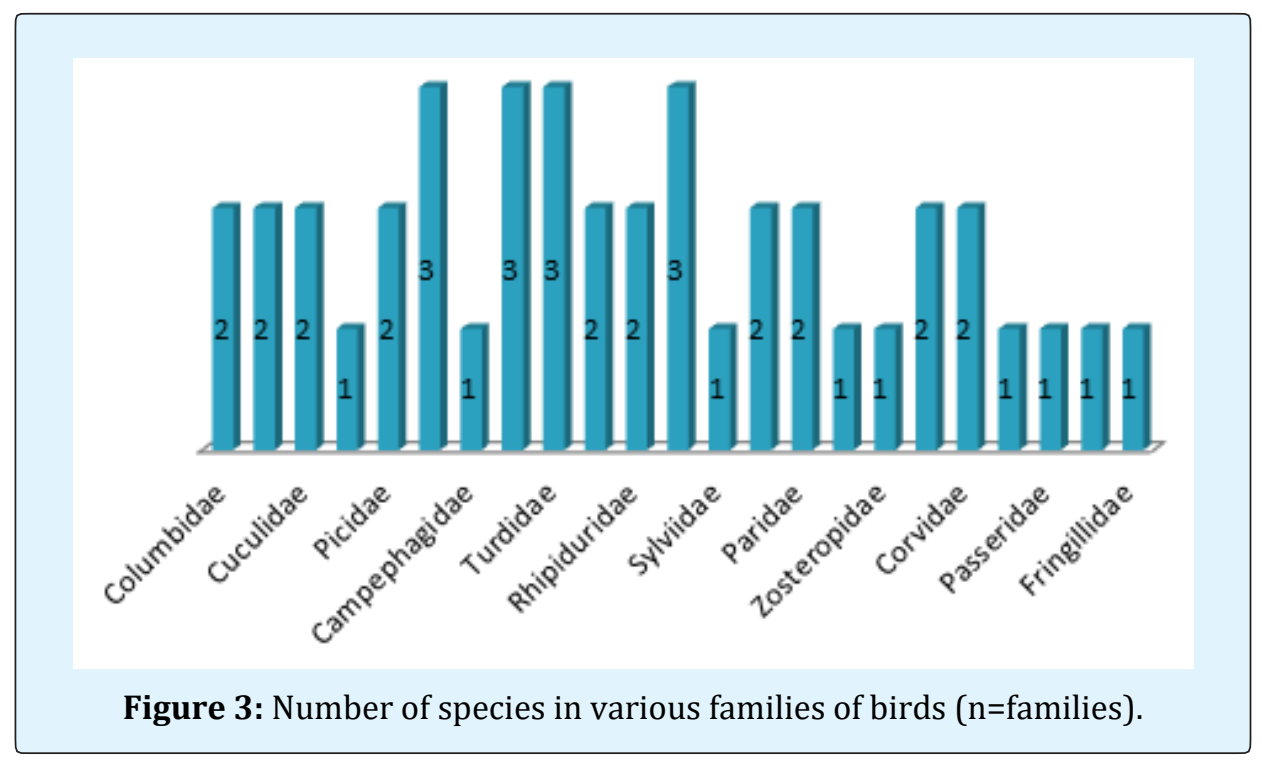

\section{The Shannon Index of a Diversity}

In the study area, the diversity index was estimated using the alpha diversity. The overall diversity index (alpha diversity) of birds in the study area was observed low $(-1232)$. The seasonal wise, the index were showed1372 in summer and -1152 in rainy seasons.

\section{Discussion}

The result of the present study reveals that the abundance of birds in the Kodanadu is also an attraction for the many tourists and even though the birds are not much more except some species of birds. These species are most beautiful coloration are attract with the charming calls, throughout year in the path of Nilgiris. The present study area (Kodanadu) in the Nilgiris harbors about 46 species of birds and it includes many endemic to Western Ghats.

According to Renuka, et al. [17] reported 32 species were also obtained in the Botanical garden Udhagamandalam many birds are higher in number in the abundance except some migratory species of birds. Similar observations were made in the boathouse area in Ooty [18]. Karthick, et al. [12] studied in selected sites in the Ketti area which was house sparrow (Passer domesticus) was higher encounter rate and Grey wagtail (Motacilla cinere) was lower encounter rate. Sudha, et al. [7] recorded the maximum individual for House sparrow (Passer domesticus) in Udhagamandalam. Similarly, the current investigations are also supporting to previous studies. The Western Ghats have one of most complex and patchy landscape in India. The Western Ghats have diverse avifauna there are 507 species of birds known from Western Ghats and adjacent narrow coast line of these 360 bird species at residents with 16 being endemic. The Nilgiris hills in the Western Ghats are known for its high endemism. According to Karthik, et al. [12] reported the strong relationship between the rainy and winter seasons for the population of different bird species. The Shannon index of alpha diversity shows the low number to indicate the diversity in the study area. Similarly Kalaiyarasi, et al. $[19,20]$ observed the higher abundance in House sparrow in Nilgiris.

The diversity (alpha diversity) of birds in the study area was observed low and the seasonal wise, the index were negative in rainy seasons obtained.

Several detailed study have been conducted on different aspect on birds in this Nilgiris region [2,21-23] Birds unimportant component of the forest ecosystem play a major role as consumer and disperser of plants, seeds and controllers of inset population. Scavenging bird species assist in cleaning environment, while others control crop and animal pests, and some serve as indicators, of changes in environmental quality. Changes in the status of birds may warm of habitat loss and modifications and can indicate the likely impact of these threats on other animals and plants. Habitat structure, diversity and their relationship with the fauna provide information about the habitat utilization which ultimately leads to the management and monitoring species, habitats and the ecosystem. 


\section{International Journal of Zoology and Animal Biology}

\section{References}

1. Gill FB (1994) Ornithology $2^{\text {nd }}$ (Edn.), Oxford University Press, New York, pp: 117.

2. Jayson V, Mathew (2002) Structure and composition of two bird communities in the Southern Western Ghats. Journal of the Bombay Natural History Society 99(10): 8-25.

3. Kershaw KA, Looney JH (1973) Sampling test of comparison and application of

4. Ali S, Ripley D (1998) Birds of India and Pakistan, together with those of Nepal, Sikkim, Bhutan and Ceylon. Bombay, New York, Oxford University Press.

5. Satterfield AJ, Cropsby MJ, Wege DC (1998) Endemic bird areas of the world; priorities for Biodiversity conservation, Cambridge, UK. Tamilnadu forest department 2007. Wildlife Biodiversity, retrived 9.7.2007. Nilgiris Biosphere Reserve

6. Robin VV, Sukumar R (2002) Status and habitat utilization of a threapened bird, White- bellied Short wing Brachypteryx major in the Western Ghats (Kerala and Tamil Nadu), India. Bird Conservation International 12(4): 335-351.

7. Sudha N (2013) Bird abundance and its diversity in and around the Rose Garden Area, Udhagamandalam, The Nilgiris. M.Sc unpublished Dissertation submitted to Bharathiar

8. Chandrasekar S (2014) Population of avian fauna in and around the Kettivillages, Coonoor, The. Nilgiris. M.Sc. Dissertation submitted to Bharathiar University, Coimbatore, TamilNadu.

9. Sivakumar C (2015) Population and diversity of avian fauna in the Emerald valley of the Nilgiris. M.Sc. Dissertation submitted to Bharathiar University, Coimbatore, TamilNadu.

10. Angel Deva Sheela A (2015) Population studies on the avian diversity in and around the Fingerpost areas, The Nilgiris, western Ghats. M.Phil unpublished Dissertation submitted to Bharathiar University, Coimbatore, pp: 119.

11. Mahalakshmi G (2015) Population ecology of grey junglefowl (Gallus sonneratii) in the Ovalley forest of the Nilgiris, Western Ghats. M.Phil unpublished
Dissertation submitted to Bharathiar University, Coimbatore, pp: 89.

12. Karthik K (2015) Status and distribution of house sparrow (Passer domesticus) in and around the Hubbathalai area of Nilgiris, western Ghats, M.Phil unpublished Dissertation submitted to Bharathiar University, Coimbatore, pp: 66.

13. Chandrasekar S (2015) Population study of Grey junglefowl (Gallus sonneratii) in the Kethi areas,

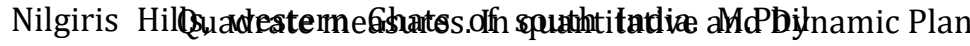
Dissertation submitted to Bharathiar University, Coimbatore, TamilNadu pp: 71.

14. Burnham KP, Anderson DR, Laake JK (1980) Estimation of density from Line Transect Sampling of biological population. Wildlife monograph 72: 1-292.

15. Buckland ST, Anderson DR, Burnham KP, Laake JL, Borchers DL, et al. (2001) Introduction to Distance Sampling: TEstimatingorAbsubelametenenf. Biological Populations. Oxford University Press, Oxford, UK.

16. Champion HG, SK Seth (1968) A Revised Survey of Forest types of India. Government of India, New Delhi, pp: 404.

17. Renuka S (2012) Abundance of Avian fauna in and around the Government Botanical Garden, Udhagamandalam, The Nilgiris. M.Sc unpublished Dissertation submitted to Bharathiar University, CoimbatoreJniversity, Coimbatore.

18. Jackur Nisha S (2012) Studies on the abundance of Avian Diversity species at Boat House Area Udhagamandalam, The Nilgiris. M.Sc. Dissertation submitted to Bharathiar University, Coimbatore, TamilNadu.

19. Kalaiyarasi G, Jayabalan D, Rameshkumar C, Subramanian C (2017) Avian Diversity and its Abundance in the Kethi Valley Areas, The Nilgiris, Western Ghats, Tamil Nadu. Int J Adv Res 5(8): 781788.

20. Kalaiyarasi G, Jeyabalan D, Rameshkumar C, Subramanian C (2019) Status and Diversity of Birds in the Doddabetta Area, The Uppernilgiris, Western Ghats. International Journal of Current Research 11(2): 1453-1457. 


\section{International Journal of Zoology and Animal Biology}

21. Islam MA (1994) Breeding habits of the Nilgiris thrush. Journal of Bombay Natural History Society 91: 16-28.

22. Islam MZ, Rahmani AR (2004) Important bird area in India. Priority sites for Conservation. IBCN, Bombay Natural History Society. Bird life international, UK pp: 1133.
23. Gokula V (1998) Bird communities of the thorn and dry deciduous forests in Mudumalai Wildlife Sanctuary, TamilNadu, South India. Unpublished Ph.D Thesis, Bharathiar University, Coimbatore, TamilNadu, India. 